\title{
Does Social Media Addiction Differ by Personality Traits? A Study on Undergraduate Tourism Students
}

\author{
Ömer Akgün Tekin \\ Akdeniz University, Antalya, Turkey \\ Alparslan Abdullah Turhan \\ Akdeniz University, Antalya, Turkey
}

Received: 5 November 2020. Revision received: 23 December 2020, 2 February 2021 Accepted: 6 March 2021

\begin{abstract}
The potential relationship between social media addiction and personality traits is an essential topic in tourism studies, though it is rarely examined. Thus, this study aims to examine whether undergraduate tourism students are addicted to social media and, if so, the possible relationship between this addiction and their personality traits. The research used the descriptive method, one of the quantitative research methods. The questionnaire technique and the convenience sampling method were preferred to amass the data. Data were collected from 454 undergraduate tourism students and analyzed with the Pearson correlation test by using SPSS 25. This research has revealed that the students' dominant personality trait is agreeableness with a low-level social media addiction. The research has also found a positive relationship between neuroticism personality traits and social media addiction and a negative relationship between personality traits of extraversion, agreeableness, and conscientiousness, and social media addiction. The research has revealed that tourism students are dependent on social media. Social media addiction is a type of addiction that harms individuals' personal development and business life. Accordingly, theoretical and practical studies should be carried out to combat this addiction. To this end, it is crucial to develop more sophisticated combating methods according to an individual's personality traits and carry out awareness and training studies in the practical field. The literature has scarcely examined the relationship between undergraduate tourism students' personality traits and social media addiction. Therefore, this study is believed to contribute to filling an important gap in the literature.
\end{abstract}

Key Words: internet, social media, social media addiction, personality traits, tourism students

JEL Classification: L83

Reference: Tekin, Ö. A., \& Turhan, A. A. (2020). Does Social Media Addiction Differ by Personality Traits? A Study on Undergraduate Tourism Students. Journal of Tourism and Services, 22(12), 23-41. doi: 10.29036/jots.v12i22.220

\section{Introduction}

The internet, a key technological platform, can be considered a powerful possibility of the $21 \mathrm{st}$ century if it is used for due purposes such as accessing information, problem-solving, and personal development (Şimşek et al., 2017). Today, internet technologies have greatly facilitated mass communication by improving communication quality, shortening time, and reducing costs (Saksiriruthai, 2018). The emergence of social media platforms can be regarded as one of the consequences of this convenience. These platforms have increased their popularity day by day, becoming a new world alternative to the real world. Especially in the last decade, the interest in social 


\section{JOURNAL OF TOURISM AND SERVICES}

Issue 22, volume 12, ISSN 1804-5650 (Online)

www.jots.cz

media platforms has now turned social media into a mass communication tool (Kot et al., 2017). However, this has caused "excessive use" of the internet in some individuals. It is a fact that some individuals cannot set their internet usage limits in line with their needs. Excessive internet use, known as internet addiction, net addiction, social media addiction, and pathological internet use, results in significant problems in business and social life (Widyanto \& Griffiths, 2007). Various studies in the literature have revealed that internet and social media addiction can cause (i) psychological problems like anxiety as well as adverse effects on personal development (Colwell \& Kato, 2003), (ii) significant negative consequences such as withdrawal and excessive engagement (Rajesh \& Rangaiah, 2020), and (iii) grave disorders like friendship difficulties, depression, poor quality of sleep, excessive mental occupation, repetitive thoughts about control of use, and failure to prevent access (Andreassen, 2015; Bowden-Green et al., 2021).

It is well-accepted that personality traits have considerable effects on human behavior. This acceptance has made the relationships between social media behavior $\&$ addiction and personality traits an essential research topic. According to Kircaburun and Griffiths (2018), "there are several theories suggesting that personality differences play an important role in developing and maintaining addictive use of different online applications." Furthermore, Chen and Roberts (2019) state that "different personalities have different motivations for using social networking sites, which may in turn lead to social networking sites addiction." In a past few decades, to examine the relationships between social media addiction and personality traits, various studies have been conducted, albeit in small numbers.

This research's main purpose has been defined as examining the relationships between undergraduate tourism students' personality traits and social media addiction, as well. There are several basic reasons for selecting the sample. The number of studies examining the relationships between social media addiction and personality traits is limited. On the other hand, the authors have not reached any study that was prepared with this aim on undergraduate tourism students. The authors believe that this is a key gap for tourism, personality and social media studies and that the findings to be obtained from the research will make a theoretical contribution to this regard. To this end, two research questions were developed in the study. One of these questions aims to determine students' personality traits, while the other seeks to determine whether the students are addicted to social media. After obtaining the findings on the research questions, it has been aimed to examine the relationships between personality traits and social media addiction. Secondly, social media use and addiction are much more common problems among young people, the most vulnerable group (Kocaman et al., 2017; Bisen \& Deshpande, 2020). It is known that this can cause psychological disorders in young people, adversely affecting their personal development (Colwell \& Kato, 2003). The authors hope that findings to be obtained from the research will reveal practical outcomes that can create an added value in the context of young people's personality traits in combating social media addiction. And finally, the young people, who constitute the study sample, are trained as future tourism professionals with a key human resource value. In this training process, students, their families and the government bear a considerable cost and invest in the future. However, possible circumstances caused by social media addiction that also trigger productivity problems in business life may aggravate this cost and investment. The fact that individuals have experienced problems in their private and business lives due to social media addiction and that human resources have thus become inefficient may cause severe problems for all parties. These problems pose risks that may adversely affect students first, and then the tourism sector and the national economy, respectively. Therefore, the authors consider that the study findings can contribute to social awareness of this issue, encouraging the relevant parties to take measures.

On this basis, the study has primarily mentioned the information about social media addiction and personality traits in the conceptual framework section and briefly has touched upon the relevant findings in the literature. Then two research questions and five hypotheses were established to accomplish the aim of the research. The study results have covered students' demographic 


\section{JOURNAL OF TOURISM AND SERVICES}

Issue 22, volume 12, ISSN 1804-5650 (Online)

www.jots.cz

characteristics, dominant personality traits, social media addiction levels, and findings between social media addiction and personality traits.

This research consists of four sections: Literature Review, Method, Results, Discussion and Conclusion. In the literature review section, the concepts of social media and five-factor personality traits are first explained theoretically. Then, the definition and occurrence of social media addiction is elaborated and the possible relationships between personality traits and social media addiction are analyzed. At the end of the section, research questions and hypotheses of the research, developed based on studies from the literature, are presented. In the methods section, the aim, methodology, population and sampling of the study are explained. Detailed information about the scales used in the research was then presented. In the results section of the study, participants' sample profile results are revealed. Then, the results of Pearson correlation analysis conducted for the hypotheses were shared. In the discussion section of the study, the findings obtained from the research questions and hypotheses tests were discussed and explained together with the findings collected from similar studies from the literature. In the conclusion section, the conclusion drawn from the research findings was disclosed and some recommendations have been made to combat social media addiction. Finally, the limitations of the research were clarified.

\section{Literature review}

Social media is a platform that people use to communicate about various activities, events and daily lives (Gavuruova et al., 2018). Social media applications bring together billions of people globally, offering highly interactive platforms where users share, discuss and change the content they create and enabling them to connect with almost all other people at any time and place (Kietzmann et al., 2011, p.241). According to Hootsuite (2020) data, 3.8 billion people worldwide are "active social media users". The emergence of major social media platforms dates back to a few decades. It is known that Six Degrees.com was founded in 1997, Friendster in 2002, LinkedIn and MySpace in 2003, Flickr and Facebook (Harvard version) in 2004, Yahoo 365 and YouTube 2005, and Facebook (corporate network) and Twitter in 2006 (Boyd \& Ellison, 2008, p.211). As of 2020, these social media platforms have reached an incredible number of active users: Facebook, 2.4 billion; YouTube, 2 billion; WhatsApp, 1.6 billion; FB Messenger, 1.3 billion; and Instagram, 1 billion. (Hootsuite, 2020). According to Hootsuite (2020) data, 54 million people in Turkey are members of social media platforms. This figure represents $64 \%$ of the total population. Internet users spend an average of 7 hours and 29 minutes a day connected to the internet. The most visited social media platforms in Turkey are YouTube, Instagram, WhatsApp, Facebook and Twitter respectively.

A growing amount of research, together with these outstanding and rapid developments, has indicated that social media use has a detrimental effect on well-being (Bowden-Green et al., 2021). In particular, widespread access to social media has led to the "excessive use" that may have adverse effects on individuals and the society as a whole (Wang et al., 2015, p.40). As cited in Wang et al. (2015, p.40), social media addiction is born out of "normal" usage habits that seem "harmless" at the beginning and that its negative effects are acknowledged by users. Still, social media benefits can seduce people into "excessive use", which may change their thinking and emotion patterns. Thus, even the rational use of social media can turn from habit to irrational behavior (Xu \& Tan, 2012). The more excessive use becomes part of normal life, the more social media addiction arises, resulting in "inability to control the use of social media" and "the disruption of other activities in an individual's life due to excessive use." (Ryan et al., 2014, p.134). Based on this point of view, social media addiction has been defined as a type of soft addiction in which habitual (or rational) use patterns turn into irrational behavior patterns (Wang et al., 2015, p.41).

In fact, social media addiction is a new form of addiction that the "internet era" we experience has introduced to our lives. The literature uses the following terms for social media addiction 


\section{JOURNAL OF TOURISM AND SERVICES}

Issue 22, volume 12, ISSN 1804-5650 (Online)

www.jots.cz

interchangeably: internet addiction (Hawi \& Samaha, 2019), social media addiction (Longobardi et al., 2020), social networking addiction (Cheak et al., 2012), social networking sites addiction (Lee, 2019), online social network dependency (Thadani \& Cheung, 2011), social media dependence (Wang et al., 2015), internet dependency (Ruiz et al., 2006), and pathological internet use (Davis, 2001).

As cited in Chou, Chou and Tyan (1998), Hatterer (1994) pointed out that the addiction may be related to a substance, action, or interaction. Accordingly, people may be addicted to food, smoking, gambling, alcohol, work, and many other things. Angres and Bettinardi-Angres (2008) define addiction as "the continued use of mood-altering addicting substances or behaviors (e.g., gambling, compulsive sexual behaviors) despite adverse consequences."

Like all other addictions, social media addiction leads to a number of psychological, physiological and social problems. According to Wang et al. (2015), individuals with social media addiction may experience productivity loss and feelings of isolation, anxiety, or depression. However, despite these adverse consequences, the social media craving tends to be extremely strong or even unbearable (Wang et al., 2015, p.40). According to another perspective, social media addicts are actually people who cannot healthily use the internet. Davis (2001, p.193) describes the healthy internet use as "using the internet for an expressed purpose in a reasonable amount of time without cognitive or behavioral discomfort." Basing on this description, it might gathered that people who can use the internet in a healthy way are the ones who can distinguish between virtual and real real-life communication. They consider the internet not as "a source of identity," but as a "helpful tool." However, it is not possible to claim that social media addicts who use social media excessively have such a rational attitude.

The authors could not notice any research examining the relationships between tourism students' social media addiction and personality traits in the literature. Still, they have determined that various studies are showing that the use of social media in the tourism sector may have adverse consequences in some cases. The literature, has also various studies (Hede \& Kellet, 2012; Tham et al., 2013; Zeng \& Gerritsen, 2014; Casado-Díaz et al., 2020; Siegel et al., 2020) that indicate social media's negative effects on tourism sector.

If social media is not properly managed, it may have negative effects rather than positive effects (Zeng \& Gerritsen, 2014). The development of social media has caused, the tourism industry and businesses to lose control over what got written about them online (Dwivedi et al., 2007). Tourism is a product based on experience. Therefore, visitors' unfavorable comments on social media can create a big "word of mouth", negatively affecting potential tourists (Hede \& Kellet, 2012; Tham et al., 2013). The possible effect of negative comments by previous visitors should not be underestimated. Xue and Zhou (2011) found that negative comments in an online community are more likely to be trusted and shared. To avoid effects of social media, the tourism sector should be able to monitor social media and interact with its customers (Grant-Braham, 2007). The sector should strive to protect itself from the negative effects of social media (Gretzel, 2019). To this end, the Vienna Tourist Board (VTB) has initiated an "anti-hashtag" campaign. Under the campaign, tourists are invited to spend their holidays without smart-phones and without being connected to social media (Buckley, 2018). To support this campaign, billboards carrying the slogan, "See Vienna, not \#Vienna", were placed around Vienna (Siegel et al., 2020). According to Seo et al. (2015), the information shared on social media reaches a broad audience at an incredible speed. Therefore, social media has a vital role in communication. Hotel managers need to be aware of this and engage more in social media to combat its negative effects. They should consider using social media to communicate with the public in case of any negative circumstances. To minimize the adverse effects, responses, explanations and due notifications, if necessary, should be made in a timely manner.

Internet addiction and social media addiction, which are sometimes used interchangeably in the literature, have overlapping concepts (Hawi \& Samaha, 2019); however, social media addiction is, in fact, one of the internet addiction subtypes. Social media addiction, one of the main factors of excessive 


\section{JOURNAL OF TOURISM AND SERVICES}

Issue 22, volume 12, ISSN 1804-5650 (Online)

www.jots.cz

internet use, may cause psychological disorders like anxiety and destructive effects on personal development (Colwell \& Kato, 2003). This addiction can also lead to (i) significant adverse effects such as withdrawal and excessive engagement (Rajesh \& Rangaiah, 2020) and (ii) a number of problems such as friendship difficulties, depression, poor quality of sleep, excessive mental occupation, repetitive thoughts about control of use, and failure to prevent access (Andreassen, 2015; Bowden-Green et al., 2021). In addition to the findings as mentioned above, several studies in the literature have revealed meaningful relationships between these internet-based addictions and certain psychological conditions and disorders. Some studies have found that there is a relationship between social media addiction and the following: ego power (Shepherd \& Edelmann (2005), shyness and personality (Saunders and Chester, 2008), anxiety Kratzer and Hegerl (2008), self-compassion (İskender \& Akın, 2011), smoking and alcohol use (Yen et al., 2009), and empathy (Kocaman et al., 2017).

It is well-established that personality is an essential factor that has traces and effects on many human behaviors. Whether social media addiction differs according to individuals' personality traits is also among the literature's key research topics. "several theories suggesting that personality differences play an important role in the development and maintenance of addictive use of different online applications" (Kircaburun \& Griffiths, 2018). In this sense, various studies in the literature (AmichaiHamburger \& Vinitzky, 2010; Hasan \& Yasir, 2016; Andreassen et al., 2017) have examined the relationships between individuals' personality traits and their social media addiction or social media usage levels, drawing remarkable conclusions. Some of these studies preferred the Five-Factor Model (FFM), which reached a certain level of maturity thanks to the works of McCrae and Costa. "In a narrow sense, the FFM of personality is an empirical generalization about the covariation of personality traits. Although the FFM is not a theory of personality, McCrae and John (1992) argued that it implicitly adopts the basic tenets of traits theory - that individuals can be characterized in terms od relatively enduring patterns of thoughts, feelings and actions; that traits can be quantitively assessed that they show some degree of cross situational consistency; and so on" (McCrae and Costa, 1999, p.140). FFM consists of five broad trait dimensions of personality. Research into the dimensions of neuroticism, extraversion, and openness to experience began in the mid-1970s. In 1983, the dimensions of agreeableness and conscientiousness were added to these dimensions (Costa \& McCrae, 2008, p.179). The FFM dimensions and their characteristics are shown in Table 1.

Table 1. FFM dimensions and characteristics

\begin{tabular}{|c|c|c|}
\hline High & Dimension & Low \\
\hline $\begin{array}{l}\text { Prone to psychological problems, } \\
\text { worried, stressed, insecure, non- } \\
\text { resilient, over-sensitive, pessimistic, } \\
\text { self-conscious, frustrated }\end{array}$ & Neuroticism (N) & $\begin{array}{l}\text { Reassuring, calm, relaxed, } \\
\text { hardy, cautious }\end{array}$ \\
\hline $\begin{array}{l}\text { Affectionate, social, active, joiner, } \\
\text { talkative, prone to living collectively }\end{array}$ & Extraversion (E) & Reserved, loner, quiet, calm \\
\hline $\begin{array}{l}\text { Imaginative, can think analytically, } \\
\text { interested in art and aesthetics, } \\
\text { sensitive, open to innovation, } \\
\text { intellectually curious, behaviorally } \\
\text { flexible, non-dogmatic in their } \\
\text { attitudes and values }\end{array}$ & $\begin{array}{l}\text { Openness to } \\
\text { experience }(0)\end{array}$ & $\begin{array}{l}\text { Down-to-earth, conventional, } \\
\text { incurious }\end{array}$ \\
\hline $\begin{array}{l}\text { Softhearted, good-natured, sincere, } \\
\text { compassionate, } \\
\text { sympathetic, open to cooperation }\end{array}$ & Agreeableness (A) & $\begin{array}{l}\text { Selfish, overly competitive, } \\
\text { critical }\end{array}$ \\
\hline Conscientious, strong-willed, goal & Conscientiousness (C) & Irresponsible, \\
\hline
\end{tabular}




\section{JOURNAL OF TOURISM AND SERVICES}

Issue 22, volume 12, ISSN 1804-5650 (Online)

www.jots.cz

\begin{tabular}{|l|l|l}
\hline and success oriented, scrupulous, & & casual, aimless
\end{tabular}

well-organized, diligent

crts, 2007; Ulu, Özdeveciŏ̌lu and Ardıç,

Source: McCrae and Costa, 1980; McCrae and Costa, 1992; Lodi-Smith and Roberts, 2007; Ulu, Özdevecioğlu and Ardıç, 2016

\section{Methods}

The research's main objective is to examine the relationships between personality traits and social media addictions of undergraduate tourism students. The three main reasons for selecting the sample of undergraduate tourism students in the study are as follows:

- Firstly, the number of studies in the literature examining the relationships between undergraduate tourism students' personality traits and social media addiction is extremely limited, thereby indicating a huge gap on the subject. It is hoped that the research findings will contribute theoretically to filling this gap.

- Secondly, the literature findings show that internet and social media addiction is more common among young people (Kocaman et al., 2017; Bisen \& Deshpande, 2020; Najafi-Sharjabad \& Rayani, 2020). Young individuals, students, singles; people from low income and low educational background are the at-risk populations for addictive social media use (Andreassen et al., 2017). Therefore, it is believed that the study findings will provide theoretical and practical contributions to undergraduate tourism students to develop more sophisticated techniques related to their personality traits in combatting social media addiction.

- Thirdly, undergraduate tourism students, who constitute the study sample, are the tourism professionals of the future and a key human resource that requires high-cost education investments. This human resource may become inefficient since social media addiction creates severe problems in individuals' private and business lives. Accordingly, the future of the educational investments may be adversely affected, which paves the way for the risks that negatively influence students, the tourism sector and the national economy, respectively. In this sense, the authors consider that the study's findings may contribute to the social awareness of the issue, encouraging the relevant parties to take measures.

The research population is a total of 1,100 students from three separate training programs at a public university in Turkey. The questionnaire technique was used as a data collection technique, and the convenience sampling method, one of the non-probabilistic sampling methods, was preferred. This method, also known as "opportunity sampling" or "accidental sampling", aims to reach easy-to-access individuals who are available and convenient (Bhattacherjee, 2012, p. 69). As per the technique and the method, 1,200 questionnaires were issued to the field. Only 636 students were surveyed in the study conducted on a voluntary basis. However, 182 of the questionnaires were discarded, seeing that they were filled incompletely or incorrectly. So the remaining 454 questionnaires were analyzed. According to Krejcie and Morgan (1970), a sample representing a population of 1,200 individuals at a 95\% confidence level with a 5\% margin of error should consist of at least 291 individuals. Since the valid number of participant questionnaires in the study is 454 , the sample is considered to represent the population quantitatively. The descriptive research method, one of the quantitative research methods, was used in the research. As cited in Tripodi and Bender (2010), descriptive researches are studies performed to describe facts, relationships, circumstances, and events regarding a sample observed by the researcher (Thomlison, 2001; Rubin \& Bobbie, 2008).

Basically, personality is a factor that affects behavior along with other factors (Andersen, 2006). In this sense, there is striking relationship between individuals' personality traits, social media usage, and social media addiction (Correa et al., 2010; Hasan \& Yasir, 2016). This research is focused on young people whom the internet and social media addiction are more widely observed (Kocaman et al., 2017; Bisen \& Deshpande, 2020; Najafi-Sharjabad \& Rayani, 2020). This research's main purpose has 


\section{JOURNAL OF TOURISM AND SERVICES}

Issue 22, volume 12, ISSN 1804-5650 (Online)

www.jots.cz

been defined as examining the relationships between undergraduate tourism students' personality traits and social media addiction, as well. To achieve this purpose, the authors have developed two research questions and five hypotheses, as follows:

- Research Question 1: What are the dominant personality traits of undergraduate tourism students under the FFM? Answering this question is a key prerequisite for determining undergraduate tourism students' dominant personality traits under the FFM.

- Research Question 2: Is the undergraduate tourism students' use of social media at the addiction level? Whether or not the undergraduate tourism students' use of social media is at the addiction level is an essential prerequisite for further analysis of the study.

The research is aimed to respond to research questions through analysis and test the hypotheses presented below.

- Various studies in the literature (Correa et al., 2010; Andreassen et al., 2013; Hasan \& Yasir, 2016) have revealed that there are positive relationships between neuroticism personality trait and social media addiction. If it is accepted that individuals with high-degree neuroticism are stressful, insecure, and overly sensitive (Table 1), it might be assumed that these individuals will have difficulty in establishing sound relationships in real life. Accordingly, it is anticipated that these individuals will drift away from real life, turning to virtual platforms. Based on this assessment, the authors have constructed the following hypothesis:

$\mathbf{H}_{1 \text { null: }}$ There is not a positive correlation between neuroticism and social media addiction.

$\mathbf{H}_{1}$ : There is a positive correlation between neuroticism and social media addiction.

- Several studies in the literature (Correa et al., 2010; Hawi \& Samaha, 2019; Marengo et al., 2020) reveal positive direction relationships between extraversion personality trait and social media addiction. If it is accept that individuals with high degrees of extraversion are social, active, talkative (Table 1) individuals, it is assumed that these individuals will want to extensively exhibit these characteristics on social media platforms. Accordingly, the authors have constructed the following hypothesis:

$\mathbf{H}_{2 \text { null: }}$ There is not a positive correlation between extraversion and social media addiction.

$\mathbf{H}_{2}$ : There is a positive correlation between extraversion and social media addiction.

- Correa et al. (2010) found a positive relationship between openness to experiences and the social media use frequency. If it is accepted that individuals with high-level openness to experiences are curious and open to innovations (Table 1), it is assumed that these characteristics can encourage them to use social media more extensively. The authors have thus constructed the following hypothesis:

$\mathbf{H}_{3 \text { null: }}$ There is not a positive correlation between openness to experiences and social media addiction.

$\mathbf{H}_{3}$ : There is a positive correlation between openness to experiences and social media addiction.

- Various studies in the literature (Hasan \& Yasir, 2016) have indicated a positive relationship between agreeableness and social media addiction. If it is accepted that individuals with highlevel agreeableness are benign, friendly, sympathetic (Table 1), it is assumed that these characteristics may encourage them to use social media more intensively. Based on this assessment, the authors have constructed the following hypothesis:

$\mathbf{H}_{4 \text { null: }}$ There is not a positive correlation between agreeableness and social media addiction.

$\mathbf{H}_{4}$ : There is a positive correlation between agreeableness and social media addiction.

- Kircaburun and Griffiths (2018) and Lee (2019) found a negative relationship between social media addiction and conscientiousness. If it is accepted that individuals with a high-degree conscientiousness level are responsible and goal and success-oriented (Table 1), it is anticipated that these individuals will more devote their time and effort to their responsibilities and therefore, use social media at a more reasonable level. In other words, it is assessed that the 


\section{JOURNAL OF TOURISM AND SERVICES}

Issue 22, volume 12, ISSN 1804-5650 (Online)

www.jots.cz

more the conscientiousness levels of these individuals increase, the less they will find time for activities like social media involvement. Based on this assessment, the authors have constructed the following hypothesis:

$\mathbf{H}_{5}$ null: There is not a negative correlation between conscientiousness and social media addiction.

$\mathbf{H}_{5}$ : There is a negative correlation between conscientiousness and social media addiction.

\section{Results}

In the study, one questionnaire and two scales were used. The questionnaire form for the determination of demographic characteristics and personality traits (sample profile) of the participants was prepared by the researchers. Being adapted into Turkish by Gümüş (2009), the Five-Factor Personality Traits Scale (FFPTs) was employed to determine the participants' personality traits under the FFM. This scale with 44-item big five inventory has been used in many studies in Turkey and has proven its validity and reliability. The five-point Likert scale was used to score the scale (1: Strongly disagree, 3: Moderately agree, 5: Strongly agree). Social Media Addiction Scale (SMAs) is a scale that has been proven to be valid and reliable in Turkish as well. This scale by Tutgun-Ünal (2015) also consists of 41 items based on four factors. The five-point Likert scale was used to score (1: Never, 3: Sometimes, 5: Always). Statements with negative meanings in the scales were reverse coded, then included in the analysis.

Explanatory factor analysis with Varimax rotation technique was used to test the internal validity of the scales. As the result of factor analysis, it was determined that the five-factor personality traits scale consists of five factors (score of total variance explained: 52,237) and the social media addiction scale consists of four factors (score of total variance explained: 60,602).

Table 2. Scales at a glance

\begin{tabular}{|l|c|l|c|}
\hline \multicolumn{2}{|c|}{ Five factor personality traits scale } & \multicolumn{2}{c|}{ Social media addiction scale } \\
\hline \multicolumn{1}{|c|}{ Factors } & Cronbach's alpha & \multicolumn{1}{c|}{ Factors } & Cronbach's alpha \\
\hline Neuroticism & .84 & Occupation & .93 \\
\hline Extraversion & .88 & Mood modification & .89 \\
\hline Openness to experiences & .81 & Relapse & .91 \\
\hline Agreeableness & .79 & Conflict & .95 \\
\hline Conscientiousness & .82 & \\
\hline \multicolumn{2}{|c|}{ Source: own research }
\end{tabular}

Social media scale factors can be summarized as follows (Tutgun-Ünal, 2015, p.136):

- Occupation: means that a person thinks about and engages in heavily social media activities. In other words, it is a state of preoccupation with social media.

- Mood modification: means that social media activities change the person's mood positively. The changes that occur during these activities make the person feel better emotionally.

- Relapse: is that a person quickly reverts back to their excessive social media use each time after they have avoided social media for a while or have tried to limit its use.

- Conflict: means that social media activities create problems in the person's relationships and interfere with their business, education, and other activities, as well as negatively affecting other duties and responsibilities in their life.

Findings on the participants' profile are shown in Table 3. 


\section{JOURNAL OF TOURISM AND SERVICES}

Issue 22, volume 12, ISSN 1804-5650 (Online)

www.jots.cz

Table 3. Sample profile

\begin{tabular}{|c|c|c|}
\hline Gender & Frequency & $\%$ \\
\hline Female & 187 & 41.2 \\
\hline Male & 267 & 58.8 \\
\hline \multicolumn{3}{|l|}{ Department } \\
\hline Tourism management & 134 & 29.5 \\
\hline Tourism \& hotel management & 181 & 39.9 \\
\hline Culinary & 139 & 30.6 \\
\hline \multicolumn{3}{|l|}{ Age } \\
\hline$<20$ & 82 & 18.1 \\
\hline $20-21$ & 278 & 61.2 \\
\hline$>21$ & 94 & 20.7 \\
\hline \multicolumn{3}{|l|}{ Average monthly income } \\
\hline$<300$ TRY & 42 & 9.3 \\
\hline 301-600 TRY & 229 & 50.4 \\
\hline 601-900 TRY & 76 & 16.7 \\
\hline$<900$ TRY & 107 & 23.6 \\
\hline
\end{tabular}

Source: own research

Table 3 shows that approximately 59\% of the participants are mostly male students and that $40 \%$ of the participants participate in the tourism \& hotel management program, $31 \%$ in the culinary program, and $29 \%$ in the tourism management program. The age-based examination revealed that the most populous group is the students between the ages of $20-21$, corresponding to $61 \%$. The examination made according to the monthly average income level shows that half of the participants have a monthly average income of 301-600 TRY.

It is examined the arithmetic mean of the participants' dominant personality traits and social media addiction levels during this stage of the study to answer the research questions 1 and 2 . The findings are presented in Table 4.

Table 4. Descriptive statistics and test of normality values of participants' personality traits and social media addiction levels

\begin{tabular}{|c|c|c|c|c|c|}
\hline \multirow{6}{*}{$\begin{array}{l}\text { Personality } \\
\text { traits }\end{array}$} & Factors & Mean & $\begin{array}{l}\text { Standard } \\
\text { deviation }\end{array}$ & Skewness & Kurtosis \\
\hline & Agreeableness & 3.83 &, 590 &,- 282 &,- 052 \\
\hline & Openness to experiences & 3.53 &, 593 &, 010 &,- 329 \\
\hline & Conscientiousness & 3.39 & ,612 &,- 145 &,- 248 \\
\hline & Extraversion & 3.24 & ,748 &,- 171 &,- 331 \\
\hline & Neuroticism & 2.95 & ,625 & 026 & ,326 \\
\hline \multirow{5}{*}{$\begin{array}{c}\text { Social } \\
\text { media } \\
\text { addiction } \\
\text { (SMA) }\end{array}$} & Occupation & 2.86 & ,923 & 170 &,- 481 \\
\hline & Mood modification & 2.68 & 1,065 & ,321 &,- 649 \\
\hline & Relapse & 2.28 & 1,031 & ,522 &,- 493 \\
\hline & Conflict & 2.12 & 961 & ,651 &,- 585 \\
\hline & Overall SMA & 2,43 & ,847 & ,469 &,- 449 \\
\hline
\end{tabular}

Source: own research 


\section{JOURNAL OF TOURISM AND SERVICES}

Issue 22, volume 12, ISSN 1804-5650 (Online)

www.jots.cz

The findings in Table 4 show that the most dominant personality trait of the students is agreeableness. However, other personality traits were also observed at significant rates. This finding answers "Research Question 1" of the study. The five-point Likert scale is divided into equal intervals by the formula $4 / 5=0.80 "$ to examine the findings on the social media addiction dimensions shown in Table 4. The examination has revealed that there is a low-level of social media addiction in all dimensions and also overall SMA with arithmetic mean value above 1.80. This finding answers "Research Question 2" of the study. In sum, the findings of Research Questions 1 and 2 reveal that the most dominant personality trait of the participants is agreeableness and that the participants have a lowlevel social media addiction.

In the study, the skewness and kurtosis values were taken into consideration to test the normality distribution of factors. According to George and Mallery, (2010) the skewness and kurtosis values of the data between -2.0 and +2.0 indicate that the data has normal distribution. For this reason (Table 4), the Pearson Correlation Analysis, as a parametric test method, was used to test the hypotheses of the research.

The correlational relationships between all the factors that constitute the scales used in the study and the results of the hypothesis tests are presented in Table 5.

Table 5. The correlational relationships between factors and findings on hypotheses

\begin{tabular}{|c|c|c|c|c|c|c|}
\hline & & Neuroticism & Extraversion & $\begin{array}{c}\text { Openness } \\
\text { to } \\
\text { experience }\end{array}$ & Agreeableness & Conscientiousness \\
\hline \multirow{2}{*}{ Occupation } & $\mathbf{r}$ & $.199^{* *}$ & $-.164^{* *}$ & -.012 & .012 & $-.192^{* *}$ \\
\hline & $\mathrm{p}$ & .000 & .000 & .798 & .801 & .000 \\
\hline \multirow{2}{*}{$\begin{array}{c}\text { Mood } \\
\text { motification }\end{array}$} & $\mathrm{r}$ & $.195^{* *}$ & $-.151^{* *}$ & -.003 & .110 & $-.160^{* *}$ \\
\hline & $\mathrm{p}$ & .000 & .001 & .955 & .190 & .001 \\
\hline \multirow{2}{*}{ Relapse } & $\mathbf{r}$ & .174 & $-.110^{* *}$ & -.049 & $-.135^{* *}$ & $-.183^{* *}$ \\
\hline & $\mathrm{p}$ & .236 & .019 & .298 & .004 & .000 \\
\hline \multirow{2}{*}{ Conflict } & $\mathbf{r}$ & $.172^{* *}$ & $-.170^{* *}$ & -.105 & $-.220^{* *}$ & $-.287^{* *}$ \\
\hline & $\mathrm{p}$ & .000 & .000 & .260 & .000 & .000 \\
\hline \multirow{2}{*}{$\begin{array}{l}\text { OVERALL } \\
\text { SMA }\end{array}$} & $\mathbf{r}$ & $.189^{* *}$ & $-.154^{* *}$ & -.072 & $-.212^{* *}$ & $-.251^{* *}$ \\
\hline & $\mathrm{p}$ & .000 & .001 & .127 & .000 & .000 \\
\hline
\end{tabular}

When Table 5 is examined, it is seen that there are some significant $(\mathrm{p}<0.05)$ relationships between the factors that constitute the five factor personality traits and social media addiction scales. However, all of these relationships are not statistically significant. It is seen that statistically significant relationships are negative and positive and the severity of these relationships are between 0.11 and 0.28 correlation coefficient. According to Taylor (1990, p.37) "the correlation coefficients $\leq 0.35$ are generally considered to present low or weak correlations".

The significance value (p) was taken into account in the acceptance or rejection of the hypotheses. If the significance value is below 0.05 , the test was considered to be significant. The correlation coefficient $(r)$ was taken into account when evaluating the strength of the relationships between variables.

Findings in Table 5 only supported the $\mathrm{H}_{1}$ and $\mathrm{H}_{5}$ hypotheses of the research. Accordingly, there is a positive but weak correlation $\left(\mathbf{H}_{1} \mathrm{r}: .189 ; \mathrm{p}\right.$ : 0.000; $\left.\mathrm{p}<0.05\right)$ between neuroticism personality trait and social media addiction. Also, there is a negative but weak correlation $\left(\mathbf{H}_{5} \mathrm{r}:-.251 ; \mathrm{p}: 0.000\right.$; $\mathrm{p}<0.05)$ between conscientiousness personality trait and social media addiction. 


\section{JOURNAL OF TOURISM AND SERVICES}

Issue 22, volume 12, ISSN 1804-5650 (Online)

www.jots.cz

In addition to the findings on the supported hypotheses, it was determined significant relationships between extraversion \& agreeableness personality traits and social media addiction. However, it was found negative and low-level relationships $\left(\mathbf{H}_{2} \mathrm{r}:-.154 ; \mathrm{p}: 0.001 ; \mathrm{p}<0.05 / \mathbf{H}_{4}\right.$ r: -.212 ; p: $0.000 ; \mathrm{p}<0.05)$ between personality traits and social media addiction, contrary to the established hypotheses. Finally, it was settled that there is no relationship $\left(\mathbf{H}_{3}\right.$ r: $\left.-.072 ; \mathrm{p}: 0.127 ; \mathrm{p}>0.05\right)$ between social media addiction and the personality trait of openness to experiences.

\section{Discussion}

The authors believe that social media-addicted tourism students, who constitute the sample of this study and who are being educated as future industry professionals, will experience addiction-related adverse consequences in their private and business lives. These adverse consequences are likely to decline their job success and career development in the medium term. To take precautions against this problem, it is considered that identifying the undergraduate tourism students' social media addiction and creating awareness of the issue are essential. Moreover, the identification of some meaningful relationships between social media addiction and students' personality traits may allow the development of more scrutinized and sophisticated techniques to support students with diverse personality traits. The literature review has not yielded any study examining social media addiction and personality traits of undergraduate tourism students. Accordingly, it is considered that this pioneering study has made an essential theoretical contribution to the literature.

The analysis performed to answer Research Question 1 has revealed that the students' dominant personality trait is agreeableness. The high agreeableness score implies that the students are softhearted, good-natured, sincere, compassionate, honest, sympathetic, and open to cooperation (Table 1). The authors believe that the qualities of the agreeableness personality trait are compatible with those of educated people. The literature has some studies (Etyemez et al., 2017; Khilji et al., 2019; Wegmann et al., 2020; Wu et al., 2020), which reveal findings on the fact that the agreeableness personality trait is among the dominant personality traits of students, although the personality traits of individuals differ.

Analysis made to answer Research Question 2 has shown that the students are social media addicts, albeit at a low level. This finding is consistent with the studies in the literature (Kocaman et al., 2017; Bisen \& Deshpande, 2020), which show that internet and social media addiction is common among young people. Face-to-face communication was necessarily more dependent on time and space before the invention of internet technologies. However, face-to-face relations have begun to be replaced by social media communications that have no time and place limits, especially with the introduction of high-tech smartphones, widespread access to the internet, social media platforms with enormous diversity that respond to the wishes and expectations of individuals. These developments cause individuals to create new lives within social media platforms, build novel worlds outside real life based on their tastes and expectations, and overuse these platforms, becoming addicted to these virtual worlds.

Five hypotheses have been established to achieve the aim of the research. Of these hypotheses, the $\mathrm{H}_{1}$ hypothesis was supported, which means that there is a positive but weak correlation ( $\mathrm{r}$. .189) between neuroticism personality trait and social media addiction. This finding is consistent with some studies in the literature (Correa et al., 2010; Andreassen et al., 2013; Hasan \& Yasir, 2016; Marengo et al., 2020). According to this finding, the more individuals experience psychological problems and become worried, stressed, over-sensitive, pessimistic, and self-conscious (Table 1), the more their social media addiction increases. It is considered that a high-level neuroticism personality trait may prevent individuals from establishing healthy relationships in real life. Individuals who cannot establish sound relationships in real life are believed to use more social media to suppress their feelings of loneliness and satisfy the need for socialisation. The study conducted by Amichai-Hamburger and Ben-Artzi, (2003) also revealed that neuroticism can cause loneliness, which is related to women's internet use. 


\section{JOURNAL OF TOURISM AND SERVICES}

Issue 22, volume 12, ISSN 1804-5650 (Online)

www.jots.cz

Furthermore, using more social media by neurotic individuals will minimize their real-life relationships over time, leading them to create an alternative virtual life on internet platforms. Thus, reduced real-life interaction may force individuals to interact solely in virtual platforms, which is likely to create a vicious circle over time. According to Ehrenberg et al. (2008) individuals with high-level neuroticism may tend to prefer online communication to offline communication due to social anxiety. Correa et al. (2010) also pointed out another characteristic of neurotic individuals by stating that "anxious and nervous people use social media platforms to seek support and company."

The second hypothesis supported in the study is $\mathrm{H}_{5}$. Analysis has shown a negative but weak correlation ( $\mathrm{r}:-.251)$ between conscientiousness personality trait and social media addiction. This finding is consistent with particular studies in the literature (Wilson et al., 2010; Tang et al., 2016; Lee, 2019). To be more specific, the higher the individual's traits of conscientious, strong-willed, goal \& success - oriented, scrupulous, well-organized, diligent (Table 1), the less social media addiction levels. If it is accepted that individuals with conscientiousness traits will devote a significant portion of their real-life time and energy to the personality development, family and work, it can be assumed that these individuals will use social media at an optimum level and in line with their goals. According to Landers and Lounsbury (2006), "more conscientious students are more engaged in structured activities like participation in clubs and organizations, studying for classes, writing papers". In support of this idea, the authors noted that conscientiousness was positively related to relative internet usage for academic purposes but negatively related to relative usage for leisure functions. Hergenhahn and Olson (2003) noted that young individuals with low levels of conscientiousness tend to behave out of self-control and therefore have a high tendency for social media addiction. According to Wilson et al. (2010), individuals with low-level conscientiousness spend too much time on social media instead of fulfilling their basic duties and responsibilities.

The $\mathrm{H}_{2}$ and $\mathrm{H}_{4}$ hypotheses were rejected according to the analysis results. Nevertheless, these hypotheses have revealed meaningful relationships. The rejected $\mathrm{H}_{2}$ hypothesis's analysis results have revealed negative and weak (r: - .154) relationships between extraversion personality trait and social media addiction. In fact, several studies in the literature (Correa et al., 2010; Wilson et al., 2010; Andreassen et al., 2013; Hasan \& Yasir, 2016) point out that there are positive relationships between social media addiction and extraversion. The results of this study contradict that part of the literature. Still, some other studies in the literature are consistent with the findings of this study (Landers \& Lounsbury, 2006; Wilson et al., 2010; Steers et al., 2016; Blachnio et al., 2017). Individuals with extraversion personality traits are affectionate, social, active, joiner, talkative, and prone to living collectively (Table 1). It is assessed that these individuals, unlike neurotic ones, can establish more successful relationships with other people from diverse social environments. Having personality traits that can establish successful interactions cannot be deemed as a justification for individuals to use social media excessively. However, this positive trait can be deemed as a key quality for some individuals to use social media more. It is believed that some extravert individuals use social media more and enhance their real-life interactions with the help of this personality trait. On the contrary, some extravert individuals are satisfied with their real-life interactions and continue their relationships under real-life platforms, preferring to spend less time on social media. According to Landers and Lounsbury (2006), "more extraverted students may be spending their discretionary time in more social activities that do not involve computer or internet usage. Conversely, introverted students may have more free time to engage in internet usage, or they may be more attracted to internet use because it is an activity where they can focus their attention and quietly immerse themselves in what is essentially solitary behavior."

The $\mathrm{H}_{4}$ hypothesis is the other hypothesis that yields significant results despite being rejected in the study. Analysis results of the $\mathrm{H}_{4}$ hypothesis showed negative and weak ( $\mathrm{r}$ : -212$)$ relationships between agreeableness personality trait and social media addiction. Various studies in the literature (Hasan \& Yasir, 2016) indicate positive relationships between social media addiction and agreeableness. The results of this study contradict that part of the literature. Still, some other studies in the literature 


\section{JOURNAL OF TOURISM AND SERVICES}

Issue 22, volume 12, ISSN 1804-5650 (Online)

www.jots.cz

are consistent with this study (Tang et al., 2016; Blachnio et al., 2017; Kircaburun \& Griffiths, 2018; Lee, 2019). Individuals with agreeableness personality traits are good-natured, sincere, honest, sympathetic, and open to cooperation (Table 1). The authors judge that individuals with these positive characters can establish successful relationships in their real-life interactions and maintain this success in their social media interactions. However, the authors should also note that having personality traits that can establish successful interactions cannot be deemed as a justification for individuals to use social media excessively. However, this positive character can be deemed as a critical quality for some individuals to use social media more.

Some studies in the literature claim that there are positive correlations (Correa et al., 2010) and negative (Blachnio et al., 2017) correlations between social media addiction and the personality trait of openness to experiences. However, the analysis of this study has revealed that the relationship between these two variables was not statistically significant. The $\mathrm{H}_{3}$ hypothesis was therefore rejected.

\section{Conclusion}

The results of this research, together with various studies in the literature, reveal several meaningful relationships between social media addiction and personality traits. However, it would not be reasonable to establish a direct cause and effect relationship in interpreting these relationships.

Visual and writing interaction with other people constitutes a significant part of social media use. Accordingly, being able to establish more successful human interaction in real-life, individuals with high extraversion, openness to experience, agreeableness, and conscientiousness scores may become social media addicts if they use these skills extensively on social media. Sometimes, these individuals may be contented with real-life interactions. High neuroticism scores may prevent individuals from establishing successful relationships in real life, which can lead them to social media relations, paving the way for the excessive use. However, on the contrary, individuals with excessive neuroticism, who fail in their real-life relationships, may not be successful in social media interactions. In other words, each personality trait has motivating and discouraging factors for the use of social media. So, advantages arising from personality traits create a suitable base for more use of social media. Nevertheless, it would be wrong to assume that this base is the direct cause of social media addiction. In another saying, personality traits may provide a fertile basis for excessive use of social media and social media addiction, but this is not the sole and sufficient justification therefor. The authors believe that claiming a particular personality trait has a key linear effect on social media addiction requires more regressive studies to be carried out with different methods.

One of the study's basic findings is the identification of social media addiction among students, albeit at a low level. The low level of social media addiction should not mean that it can be ignored. Yet, Wang et al. (2015, p.40) state that social media addiction arises from normal usage habits that seem harmless. Xu and Tan (2012) have explained that this normal and harmless-looking habit changes individuals' thinking and feeling patterns over time, encouraging the "excessive use" of social media. In this way, even the rational social media use may transform from normal habit to irrational behavior. To combat social media addiction observed in undergraduate tourism students, the authors have developed the following measures:

- To investigate the relationship between social media addiction and personality traits of undergraduate tourism students, and more specifically, examine the cause and effect relationships between personality traits and social media addiction through meticulous researches supported by regression analyses,

- To conduct more comprehensive studies on social media addiction by using qualitative and quantitative research methods,

- To identify other factors that cause social media addiction in undergraduate tourism students, other than personality traits, 


\section{JOURNAL OF TOURISM AND SERVICES}

Issue 22, volume 12, ISSN 1804-5650 (Online)

www.jots.cz

- To create educational content to inform undergraduate tourism students about social media addiction and train them on the issue.

It is thought that tourism professionals may have problems with social media addiction too. Some suggestions have thus been developed.

Human resources departments should:

- Support professionals who want to combat social media addiction,

- Develop awareness programs on social media addiction,

- Organize training programs and seminars to combat social media addiction.

- Cooperate with experts and academics working on social media addiction.

- Trade unions and non-governmental organizations operating in the tourism sector should carry out awareness studies on the topic.

There are several limitations to the present study. First, the sample of the study consist of a single university. Secondly, the sample size reached in the study may not be sufficient for comprehensive assessments. Thirdly, participants' attitudes towards social media only reflect a limited period in which data was collected. And last but not least, their social media perception may change positively or negatively over time.

\section{References}

1. Amichai-Hamburger, Y., \& Ben-Artzi, E. (2003). Loneliness and internet use. Computers in Human Behavior, 19(1), 71-80. https://doi.org/10.1016/S0747-5632(02)00014-6

2. Amichai-Hamburger, Y., \& Vinitzky, G., (2010). Social network use and personality. Computers in Human Behavior, 26(6), 1289-1295. https://doi.org/10.1016/j.chb.2010.03.018

3. Andersen, J. A. (2006). Leadership, personality and effectiveness. The Journal of Socio-Economics 35(2006), 1078-1091. https://doi.org/10.1016/j.socec.2005.11.066

4. Andreassen, C.S., (2015). Online social network site addiction: A comprehensive review. Current Addiction Reports, (2), 175-184. https://doi.org/10.1007/s40429-015-0056-9

5. Andreassen, C., Griffiths, M. D., Gjertsen, S., Krossbakken, E., Kvam, S., \& Pallesen, S. (2013). The relationships between behavioral addictions and the five-factor model of personality, Journal of Behavioral Addictions JBA,2(2), 90-99. https://doi.org/10.1556/iba.2.2013.003

6. Andreassen, C.S., Pallesen, S. and Griffiths, M.D. (2017). The relationship between addictive use of social media, narcissism, and self-esteem: Findings from a large national survey. Addictive behaviors, (64), 287-293. https://doi.org/10.1016/j.addbeh.2016.03.006

7. Angres, D. H., \& Bettinardi-Angres, K. (2008). The disease of addiction: Origins, treatment, and recovery. Dis. Mon., 54 (10), 696-721. https://doi.org/10.1016/i.disamonth.2008.07.002

8. Bhattacherjee, A. (2012). Social science research: principles, methods and practices. Textbook collection, (2. Edition). University of South Florida, USA: Available online: https: $/ /$ scholarcommons.usf.edu/cgi/viewcontent.cgi?article $=1002 \&$ context $=$ Oa textbooks (Accessed on 27 December 2020).

9. Bisen, S. S., \& Deshpande,Y.(2020). Prevalence, predictors, psychological correlates of internet ddiction among college students in India: A comprehensive study. Anatolian Journal of Psychiatry, 21(2), 117-123. . https://doi.org/10.5455/apd.47328

10. Błachnio, A., Przepiorka, A., Senol-Durak, E., Durak, M., \& Sherstyuk, L. (2017). The role of personality traits in Facebook and internet addictions: A study on Polish, Turkish, and Ukrainian samples. Computers in Human Behavior, 68, 269-275. https://doi.org/10.1016/j.chb.2016.11.037 


\section{JOURNAL OF TOURISM AND SERVICES}

Issue 22, volume 12, ISSN 1804-5650 (Online)

www.jots.cz

11. Bowden-Green, T., Hinds, J., \& Joinson, A. (2021). Understanding neuroticism and social media: A systematic review. Personality and Individual Differences, 168(2021), 1-12. https://doi.org/10.1016/i.paid.2020.110344

12. Boyd, D. M., \& Ellison, N. B. (2008). Social network sites: Definition, history, and scholarship. Journal of Computer-Mediated Communication, 13, 210-230. https://doi.org/10.1111/j.1083$\underline{6101.2007 .00393 . \mathrm{x}}$

13. Buckley, J. (2018). Vienna is urging tourists to ditch Instagram for a bashtag-free visit in a new tourism campaign. Available online: https://inews.co.uk/inews-lifestyle/travel/vienna-instagramholidaytourism-campaign-hashtag-free-unhashtag/ (Accessed on 28 December 2020).

14. Casado-Díaz, A. B., Andreu, L., Beckmann, S. C., \& Miller, C. (2020) Negative online reviews and webcare strategies in social media: effects on hotel attitude and booking intentions, Current Issues in Tourism, 23:4, 418-422, https://doi.org/10.1080/13683500.2018.1546675

15. Cheak, A. P. C., Goh, G. G. G., \& Chin, T. S. (2012). Online social networking addiction among university students in Malaysia. International Journal on Social Science Economics and Art, 2(4), 21-27. Available online: https://scholar.google.com/ (Accessed on 27 December 2020).

16. Chen, A., \& Roberts, N. (2019). Connecting personality traits to social networking site addiction: The mediating role of motives. Information Technology \& People, 33(2), 633656. https://doi.org/10.1108/ITP-01-2019-0025

17. Chou, C., Chou, J. and Tyan, N. N. (1998). An Exploratory Study of Internet Addiction, Usage and Communication Pleasure. Paper presented at 1998 AECT National Convention, February 18-22, 1998St. Louis, MI. US. Available online: https://files.eric.ed.gov/fulltext/ED416838.pdf (Accessed on 27 December 2020).

18. Colwell, J., \& Kato, M. (2003). Investigation of the relationship between social isolation, Selfesteem, aggression and computer game play in Japanese adolescents. Asian Journal of Social Psychology, (6), 149-158. https://doi.org/10.1111/1467-839X.t01-1-00017

19. Correa, T., Hinsley, A.W. and De Zuniga, H.G. (2010). Who interacts on the Web?: The intersection of users' personality and social media use. Computers in Human Behavior, 26(2), $247-$ 253. https://doi.org/10.1016/j.chb.2009.09.003

20. Costa, P. T. Jr. \& McCrae, R. R. (2008). The revised NEO personality inventory (NEO-PI-R). In The SAGE Handbook of Personality Theory and Assesment, Gregory J. Boyle, Gerald Matthews, Donald H. Saklofske (Eds.), SAGE, 179-198. https://doi.org/10.4135/9781849200479.n9

21. Davis, R. (2001). A cognitive-behavioral model of pathological Internet use. Computers in Human Behavior, 17, 187-195. https://doi.org/10.1016/S0747-5632(00)00041-8

22. Dwivedi, M., Shibu, T.P., \& Venkatesh, U. (2007), "Social software practices on the internet: Implications for the hotel industry", International Journal of Contemporary Hospitality Management, Vol. 19 No. 5, pp. 415-426. https://doi.org/10.1108/09596110710757570

23. Ehrenberg A, Juckes S, White K.M, \& Walsh S.P. (2008) Personality and self-esteem as predictors of young people's technology use. Cyberpsychol Behav, 11(6):739-41 https://doi.org/10.1089/cpb.2008.0030

24. Etyemez, S., Pektaş, F., \& Akyol, F. (2017). Comparison of students' personality traits accorging to their academic unit, The Journal of International Social Research, 10(52), 1036-1044. http://dx.doi.org/10.17719/jisr.2017.1957

25. Gavurova, B., Bacik, R., Fedorko, R., \& Nastisin, L. (2018). The customer's brand experience in the light of selected performance indicators in the social media environment. Journal of Competitiveness, 10(2), 72-84. Available online: https://www.cjournal.cz/files/286.pdf, (Accessed on 31 December 2020).

26. George, D., \& Mallery, M. (2010). SPSS for Windows Step by Step: A Simple Guide and Reference, 17.0 update (10a ed.) Boston: Pearson 


\section{JOURNAL OF TOURISM AND SERVICES}

Issue 22, volume 12, ISSN 1804-5650 (Online)

www.jots.cz

27. Grant-Braham, B. (2007). The social media and travel chatter.Hospitality in Focus (2007,September), Available online: http://eprints.bournemouth.ac.uk/13634/2/Croner Hospitality in Focus 14th September 2007.pdf. (Accessed on 27 December 2020).

28. Gretzel, U. (2019). The role of social media in creating and addressing overtourism. In R. Dodds \& R. W. Butler (Eds.), Overtourism: Issues, Realities and Solutions (pp. 62-75). Berlin: De Gruyter.

29. Gümüş, Ö. D. (2009). Kültür, değerler, kișilik ve siyasal ideoloji arasındaki ilișkiler: Kültürlerarası bir karşılaştırma (Türkiye-ABD). Unpublished doctorate dissertation. Ankara University, Turkey.

30. Hasan, T., \& Yasir, H. (2016). Am I a Facebook addict?" An investigation of Facebook addiction using personality traits through SEM. Journal of Organisational Studies and Innovation, 3(4), Winter, 15-31. Available online: http://journal.mbacademy.org.uk/ (Accessed on 27 December 2020).

31. Hawi, N., \& Samaha, M. (2019). Identifying commonalities and differences in personality characteristics of internet and social media addiction profiles: Traits, self-esteem, and self-

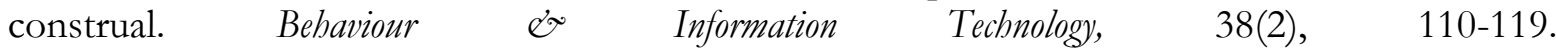
https://doi.org/10.1080/0144929X.2018.1515984

32. Hede, A.-M., \& Kellett, P. (2012). Building online brand communities: Exploring the benefits, challenges and risks in the Australian event sector. Journal of Vacation Marketing, 18(3), 239250. https://doi.org/10.1177/1356766712449370

33. Hergenhahn B., \& Olson M. (2003). An introduction to theories of personality (6th ed.). New Jersey: Prentice Hall, New York.

34. Hootsuite (2020). Digital 2020: 3.8 billion people use social media. Hootsuite (We Are Social) Ltd. Available online: https://wearesocial.com/digital-2020 (Accessed on 27 December 2020).

35. İskender, M., \& Akin, A. (2011). Self-compassion and internet addiction. The Turkish Online Journal of Educational Technology, 10(3), 215-221. https:// files.eric.ed.gov/fulltext/EJ944970.pdf

36. Khilji H. M., Shahzadi S., \& Zahoor A. (2019). Gender differences on personality traits and intelligence quotient levels during admission in medical college (QIMS). J Med Sci, 27:(3) 169174. https://www.jmedsci.com/index.php//medsci/article/view/727

37. Kircaburun, K ., \& Griffiths, M. D. (2018). Instagram addiction and the Big Five of personality: The mediating role of self-liking. Journal of Behavioral Addictions 7(1), 158-170. https://doi.org/10.1556/2006.7.2018.15

38. Kietzmann, J.H., Hermkens, K., McCarthy, I. P., \& Silvestre, B.S. (2011). Social media? Get serious! Understanding the functional building blocks of social media. Business Horizons, 54, 241 251. https://doi.org/10.1016/j.bushor.2011.01.005

39. Kocaman, O., Aktepe, E., \& Sönmez, Y. (2017). Isparta il merkezi lise öğrencilerinde olas1 internet bağımlılı̆̆ ile saldırganlık ve empati düzeyleri arasındaki ilişkinin incelenmesi. Anatolian Journal of Psychiatry, 18(6):602-610. https://doi.org/10.5455/apd.260925

40. Kot, S., Tan, M., \& Dragolea, L. (2017), The use of social media supporting studying. Economics and Sociology, 10(1), 169-180. https://doi.org/10.14254/2071-789X.2017/10-1/12

41. Krejcie, R. V., \& Morgan, D. W. (1970). Determining sample size for research activities. Educational and Psychological Measurement, https://doi.org/10.1177/001316447003000308

42. Kratzer, S., \& Hegerl, U. (2008). Is "internet addiction" a disorder of its own?-A study on subjects with excessive internet use. Psychiatr Prax, 35(2), 80-83. https://doi.org/10.1055/s2007-970888

43. Landers, R. N., \& Lounsbury, J. W. (2006). An investigation of Big Five and narrow personality traits in relation to Internet usage. Computers in Human Behavior, 22(2006), 283-293. https://doi.org/10.1016/j.chb.2004.06.001 


\section{JOURNAL OF TOURISM AND SERVICES}

Issue 22, volume 12, ISSN 1804-5650 (Online)

www.jots.cz

44. Lee, S.- L. (2019). Predicting SNS addiction with the Big Five and the Dark Triad. Cyberpsychology: Journal of Psychosocial Research on Cyberspace, 13(1), 1-12.Thadan https://doi.org/10.5817/CP20191-3

45. Lodi-Smith, J., \& Roberts, B. W. 2007. Social investment and personality: A meta-analysis of the relationship of personality traits to investment in work, family, religion, and volunteerism. Personality and Social Psychology Review, 11, 68-86. https://doi.org/10.1177/1088868306294590

46. Longobardi, C., Settanni, M., Fabris, M. A., Marengo, D. (2020). Follow or be followed: Exploring the links between Instagram popularity, social media addiction, cyber victimization, and subjective happiness in Italian adolescents. Children and Youth Services Review, 113, 104955. https://doi.org/10.1016/i.childyouth.2020.104955

47. Marengo, D., Poletti, I., \& Settanni, M. (2020). The interplay between neuroticism, extraversion, and social media addiction in young adult Facebook users: Testing the mediating role of online activity using objective data. Addictive Behaviors, 102(2020), 1-5. https://doi.org/10.1016/j.addbeh.2019.106150

48. McCrae, R. K., \&. Costa, P. T., Jr. (1980). Openness to experience and ego level in Loevingers sentence-completion test: Dispositional contributions to developmental models of personality. Journal of Personality and Social Psychology, 39, 1179-1190. https://doi.org/10.1037/h0077727

49. McCrae, R. R. And Costa, P.T. Jr. (1992). Normal personality assessment in clinical practice: The NEO personality inventory. Psychological Asssessment, 4(1), 5-13. https://doi.org/10.1037/10403590.4.1.5

50. McCrae, R. R. And Costa, P.T. Jr. (1999). A five factor theory of personality. In L. A. Pervin \& O. P. John (Eds.), Handbook of Personality: Theory and Research, (2nd ed.). New York: Guilford, 1999.

51. Najafi-Sharjabad, F., \& Rayani, M. (2020). Evaluation of internet addiction and mental health status among medical sciences students in Bushehr, southwest of Iran. Malaysian Journal of Medicine Health Sciences, 16(1), 196-202. https://medic.upm.edu.my/upload/dokumen/2020011612162229 MJMHS 0191.pdf

52. Rajesh, T., \& Rangaiah, B. (2020). Facebook addiction and personality. Heliyon, 6 (2020), 1-6. https://doi.org/10.1016/j.heliyon.2020.e03184

53. Ruiz Mafé, C., \& Sanz Blas, S. (2006). Explaining Internet dependency: An exploratory study of future purchase intention of Spanish Internet users. Internet Research, 16(4), 380-397. https://doi.org/10.1108/10662240610690016

54. Ryan, T., Chester, A., Reece, J., \& Xenos, S. (2014). The uses and abuses of Facebook: A review of Facebook addiction. Journal of Behavioral Addictions, 3(3), 133-148. https://doi.org/10.1556/iba.3.2014.016

55. Saksiriruthai, S. (2018). Impact of media technology on wage changes: The case of Thailand. Journal of International Studies, 11(4), 69-78. https://doi.org/10.14254/2071-8330.2018/11-4/5

56. Saunders, P. L., \& Chester, A. (2008). Shyness and the internet: Social problem or panacea?. Computers in Human Behavior, (24),2649-2658. https://doi.org/10.1016/i.chb.2008.03.005

57. Seo, S., Almanza, B., Miao, L., \& Behnke, C. (2015). The effect of social media comments on consumers' responses to food safety information. Journal of Foodservice Business Research, 18(2), 111-131. https://doi.org/10.1080/15378020.2015.1029384

58. Shepherd, R.M. \& Edelmann, R. J. (2005). Reasons for internet use and social anxiety. Personality and Individual Differences, (39), 949-958. https://doi.org/10.1016/i.paid.2005.04.001

59. Siegel, L., A., Tussyadiah, I., \& Scarles, C. (2020). Does Social Media Help or Hurt Destinations? A Qualitative Case Study. e-Review of Tourism Research (eRTR), 17( 4), 571-580. Available online: https://journals.tdl.org/ertr/index.php/ertr/article/view/541 (Accessed on 27 December 2020). 


\section{JOURNAL OF TOURISM AND SERVICES}

Issue 22, volume 12, ISSN 1804-5650 (Online)

www.jots.cz

60. Steers, M. N., Quist, M. C., Bryan, J. L., Foster, D. W., Young, C. M., \& Neighbors, C. (2016). I want you to like me: Extraversion, need for approval, and time on Facebook as predictors of anxiety. Translational Issues in Psychological Science, (2), 283-293. https://doi.org/10.1037/tps0000082

61. Şimşek, A., Elçiyar, K., \& Kızılhan, T. (2017). A comparative study on social media addiction of high school and university students. Paper presented at the International Association for Development of the Information Society (IADIS) International Conference on Educational Technologies (5th, Sydney, Australia, Dec 11-13, 2017). Available online: https://files.eric.ed.gov/fulltext/EJ1213656.pdf(Accessed on 27 December 2020).

62. Tang, J.-H., M.-C. Chen, C.-Y. Yang, T.-Y. Chung, and Y.-A. Lee. 2016. Personality traits, interpersonal relationships, online social support, and Facebook addiction. Telematics and Informatics, 33(1), 102-108. https://doi.org/10.1016/j.tele.2015.06.003

63. Taylor, R. (1990). Interpretation of the Correlation Coefficient: A Basic Review. Journal of Diagnostic Medical Sonography, 6(1), 35-39. https://doi.org/10.1177/875647939000600106

64. Thadani, D. R., \& Cheung, C. M. K. (2011). Online social network dependency: Theoretical Development and Testing of Competing Models, Proceedings of 44th HICSS, IEEE, Koloa, Kauai, Hawaii, 2011,1-9. Available online: https://ieeexplore.ieee.org/stamp/stamp.jsp?tp=\&arnumber=5718719 (Accessed on 27 December 2020).

65. Tham, A., Croy, G., \& Mair, J. (2013) Social media in destination choice: distinctive electronic word-of-mouth dimensions, Journal of Travel \& Tourism Marketing, 30:1-2, 144155, https://doi.org/10.1080/10548408.2013.751272

66. Tripodi, S. J., \& Bender, K. (2010). The handbook of social work research methods. in: Chapter 7: Descriptive Studies, (Ed. Bruce A. Thyer), California, USA: SAGE Publishing.

67. Tutgun-Ünal, A. (2015). Sosyal medya bağımllhğg: üniversite ögrencileri üzerine bir uygulama. Unpublished doctorate dissertation, Marmara University, İstanbul.

68. Ulu, S, Özdevecioğlu, M., \& Ardıç, K. (2016). Kişilik özelliklerinin hasta iken işe gelme (presenteizm) davranış1 üzerindeki etkileri: İmalat sanayiinde bir araştırma. Erciyes Üniversitesi İBF Dergisi, (47), 167-181. https://dergipark.org.tr/tr/pub/erciyesiibd/issue/28009/297429

69. Wang, C., Lee, M. K. O., \& Hua, Z. (2015). A theory of social media dependence: Evidence from microblog users. Decision Support Systems, (69), 40-49. https://doi.org/10.1016/i.dss.2014.11.002

70. Wegmann, J. Marshal, J. Chou-Yu, T. and Shelley, D. (2020) Health education and changing stress mindsets: the moderating role of personality, American Journal of Health Education, 51:4, 244-256, https://doi.org/10.1080/19325037.2020.1767002

71. Widyanto, L., \& Griffiths, M. (2007). Internet addiction: Does it really exist? (revisited). In J. Gackenbach (Ed.), Psychology and the internet: Intrapersonal and transpersonal implications (p. 141-63) (2nd ed.). San Diego, CA: Academic Press.

72. Wilson, K., Fornasier, S. and White, K.M. (2010). Psychological predictors of young adults' use of social networking sites. Cyberpsychology, behavior, and social networking, 13(2), 173-177. https://doi.org/10.1089/cyber.2009.0094

73. Wu, S., Zhang, K., Zhou, S., \& Chen, W. (2020). Personality and career decision-making selfefficacy of students from poor rural areas in China. Social Behavior and Personality: An international Journal, 48(5), e8753 https://doi.org/10.2224/sbp.8753

74. Xu, H., and Tan, B. C. Y. (2012). Why do I keep checking Facebook: Effects of message characteristics on the formation of social network services addiction. International Conference on Information Systems, ICIS 2012,(1), 812-823. Available online: https://scholarbank.nus.edu.sg/handle/10635/78432 (Accessed on 27 December 2020). 


\section{JOURNAL OF TOURISM AND SERVICES}

Issue 22, volume 12, ISSN 1804-5650 (Online)

www.jots.cz

75. Xue, F., \& Zhou, P. (2010) The effects of product involvement and prior experience on Chinese consumers' responses to online word of mouth, Journal of International Consumer Marketing, 23:1, 45-58, https://doi.org/10.1080/08961530.2011.524576

76. Yen, J., Ko, C., Yen, C., Chen, C., \& Chen, C. (2009). The association between harmful alcohol use and Internet addiction among college students: Comparison of personality. Psychiatry and Clinical Neurosciences, 63, 218-224. https://doi.org/10.1111/j.1440-1819.2009.01943.x

77. Zeng, B., \& Gerritsen, R. (2014). What do we know about social media in tourism? A review,Tourism Management Perspectives, 10(2014), 27-36, https://doi.org/10.1016/j.tmp.2014.01.001.

\section{Brief description of Authors:}

\section{Ömer Akgün Tekin (Ph.D.)}

ORCID ID: 0000-0002-4612-2316

Affiliation: Department of Gastronomy and Culinary Arts, Manavgat Tourism Faculty, Akdeniz University.

Email: dr.omerakguntekin@gmail.com

Address: Manavgat Tourism Faculty, Akdeniz University, Antalya, Turkey

Institutional web site: http://aves.akdeniz.edu.tr/omeratekin/

He is an associate professor in the department of gastronomy and culinary arts of Manavgat Tourism Faculty at the Akdeniz University, in Antalya, Turkey. He obtained his master's and doctorate degrees from the department of tourism and hotel management of Akdeniz University. His research interests include; tourism and hospitality management, halal tourism and organizational behavior in tourism.

\section{Alparslan Abdullah Turhan (MSc.)}

ORCID ID: 0000-0002-2805-7119

Affiliation: Deparment of Internatiional Trade, Social Sciences Vocational School of Higher Education, Akdeniz University.

Email: turhan07@gmail.com

Address: Social Sciences Vocational School of Higher Education, Akdeniz University, Antalya, Turkey Institutional web site: http://aves.akdeniz.edu.tr/abdullahturhan/

He is a lecturer in the department of international trade of Social Sciences Vocational School of Higher Education at the Akdeniz University, in Antalya, Turkey. He obtained his master's degree from the department of tourism and hotel management of Suleyman Demirel University. His research interests include; tourism and hospitality management, halal tourism, e-trade and social media. 